\title{
Pengaruh Penggunaan Media Pembelajaran Berbasis Web Terhadap Motivasi dan Hasil Belajar Mahasiswa STTIKOM Insan Unggul
}

Hetty Herawati ${ }^{1}$, Afrasim Yusta ${ }^{2}$, Susy Katerina Sianturi ${ }^{3}$

1,2Manjemen Informatika, STTIKOM Insan Unggul, ${ }^{3}$ Sistem Informasi, STTIKOM Insan Unggul E-mail: hettyhera96@gmail.com, afrasimyusta@gmail.com, susykaterina@gmail.com

\begin{tabular}{l}
\hline Article Info \\
\hline Article History \\
Received: $2021-11-01$ \\
Revised: 2021-11-25 \\
Published: 2021-12-05
\end{tabular}

Keywords: Learning Media; Motivation;

Learning outcomes.

\begin{abstract}
The purpose of this study was to determine: 1) The effect of using Web-Based Learning media on the learning motivation of STTIKOM Insan Unggul students. 2) The influence of using Web-Based Learning media on the learning outcomes of STTIKOM Insan Unggul students. This research was conducted by providing web learning for the experimental group and conventional learning for the control group. The method used is a demo. After the learning process is complete, student learning outcomes will be measured by tests and student motivation will be measured by questionnaires. Results Based on the analysis of the data obtained, it shows that the pre-test data and the posttest motivation data for both classes are $>0.05$, thus it can be said that the two data are homogeneous. Furthermore, it can be said that there is a significant increase in the average value before and before using web-based learning media. This shows that the use of learning media has a positive effect on student motivation and learning outcomes.
\end{abstract}

\begin{tabular}{l}
\hline Artikel Info \\
\hline Sejarah Artikel \\
Diterima: $2021-11-01$ \\
Direvisi: 2021-11-25 \\
Dipublikasi: 2021-12-05
\end{tabular}

\section{Abstrak}

Tujuan dari penelitian ini adalah untuk mengetahui: 1) Pengaruh penggunaan media Pembelajaran Berbasis Web terhadap motivasi belajar Mahamahasiswa STTIKOM Insan Unggul 2) Pengaruh penggunaan media Pembelajaran Berbasis Web terhadap hasil belajar Mahasiswa STTIKOM Insan Unggul. Penelitian ini dilakukan dengan memberikan pembelajaran web untuk kelompok eksperimen dan pembelajaran konvensional untuk kelompok kontrol. Metode yang digunakan adalah demonstrasi.

Kata kunci:

Media Pembelajaran; Motivasi;

Hasil Belajar. motivasi dari siswa akan diukur dengan angket. Berdasarkan hasil analisis data yang diperoleh ini menunjukkan bahwa data pre-test serta data posttes motivasi kedua Kelas $>0,05$, dengan demikian dapat dikatakan kedua data homogen. Selanjutnya dapat disimpulkan adanya peningkatan nilai rata-rata yang signifikan baik sebelum dan sesudah menggunakan media pembelajaran berbasis web. Hal ini menunjukkan bahwa penggunaan media pembelajaran berpengaruh positif terhadap motivasi dan hasil belajar mahasiswa.

\section{PENDAHULUAN}

Perkembangan ilmu pengetahuan dan teknologi (IPTEK) telah membawa perubahan pada aspek kehidupan manusia, perkembangan tersebut telah mengubah paradigma manusia dalam mencari dan mendapatkan informasi semakin mudah. Salah satu bidang yang mendapatkan dampak yang cukup berarti dalam perkembangan IPTEK adalah bidang pendidikan, dimana pada dasarnya pendidikan merupakan suatu proses komunikasi dan informasi antara dosen kepada mahasiswa yang berisi informasiinformasi pembelajaran sebagai media sarana penyajian ide, gagasan dan materi pembelajaran. Salah satu produk teknologi informasi dalam dunia Pendidikan ialah e-learning atau pembelajaran elektronik. Dengan e-learning pembelajaran bertransformasi pada sistem digital yang terhubung dengan internet. Dengan menggunakan internet baik dosen maupun mahasiswa memudahkan untuk mendapatkan informasi dari berbagai sumber. Dengan demikian baik dosen maupun mahasiswa dapat lebih memanfaatkan fasilitas yang telah dikembangkan oleh para ahli tersebut, media pembelajaran merupakan suatu alat atau perantara yang digunakan dalam proses kegiatan belajar dan mengajar, agar komunikasi antara dosen dan mahasiswa dapat berjalan efektif. Di dalam proses kegiatan belajar mengajar diperlukan media pembelajaran untuk membangkitkan keinginan dan minat belajar bagi mahasiswa, membangkitkan motivasi belajar bahkan bisa memberikan pengaruh psikologi yang baik bagi mahasiswa tersebut, salah satu usaha untuk meningkatkan kualitas proses pembelajaran adalah dengan memfasilitasi pembelajaran dengan media tertentu. Web 
merupakan salah satu jenis media yang dapat digunakan dosen untuk meningkatkan kualitas proses pembelajaran. Dosen dapat memanfaatkan Web sebagai media informasi bahan belajar, sekaligus sarana bagi para mahasiswa untuk mengakses informasi yang lebih luas dengan arahan dosen, Dosen dan mahasiswa secara bersama-sama dapat memperoleh informasi bahan belajar melalui penggunaan Web. Dari penggunaan Web sebagai media pembelajaran dapat diketahui keaktifan mahasiswa yang dimiliki saat proses pembelajaran.

Media pembelajaran yang dapat digunakan banyak sekali diantaranya dapat berbentuk gambar, bagan, model maupun media elektronik. Sebagai seorang pengajar dapat memilih bentuk media pembelajaran yang mana yang akan dipilih. Berdasarkan observasi yang dilakukan oleh peneliti di kampus STTIKOM Insan Unggul Cilegon bahwa mahasiswa masih bersifat pasif dalam kegiatan pembelajaran di kelas, mahasiswa kurang aktif dalam memberikan pertanyaan atau menjawab pertanyaan yang diberikan oleh dosen. Metode yang dikembangkan oleh dosen adalah ceramah yang sesekali di selingi dengan kegiatan tanya jawab, sehingga proses belajar mengajar hanya didominasi oleh dosen dan mahasiswa yang mempunyai daya tangkap yang baik saja. Pembelajaran bersifat diskusipun hanya didominasi mahasiswa yang memiliki kemampuan komunikasi yang baik dan pintar saja. Walaupun sudah memasuki era digitalisasi peneliti masih menemukan dosen-dosen yang menggunakan metode pembelajaran konvensional yaitu metode ceramah. Penggunaan media pembelajaran yang ada di Sistem Informasi Akademik (SIAKAD), dosen hanya melakukan aktifitas upload materi dan tugas, serta input nilai mahasiswa. Sehingga tujuan pembelajaran yang diharapkan kurang tercapai maksimal. Dengan demikian, berangkat dari beberapa persoalan di atas dalam penelitian ini peneliti ingin mengetahui Pengaruh Penggunaan Media Pembelajaran Berbasis Web Terhadap Motivasi dan Hasil Belajar Mahasiswa STTIKOM Insan Unggul. Pada penelitian ini peneliti menggunakan metode eksperimen sedangkan tujuan dari penelitian ini adalah untuk mengetahui pengaruh penggunaan media pembelajaran berbasis web terhadap motivasi dan hasil belajar mahasiswa STTIKOM Insan Unggul.

\section{A. Media Pembelajaran}

Definisi dari media yang berasal dari bahasa latin dan merupakan bentuk jamak dari kata medium yang secara harfiah berarti perantara atau pengantar. Media adalah segala sesuatu yang dapat digunakan untuk menyalurkan pesan dari pengirim ke penerima sehingga dapat merangsang pikiran, perasaan, perhatian siswa sedemikian rupa sehingga proses belajar terjadi (Sadirman, 2011:6). Dengan kata lain media adalah komponen sumber belajar atau wahana fisik yang mengandung materi instruksional di lingkungan siswa untuk belajar. Pembelajaran dilihat sebagai sebuah sistem yang terdiri dari berbagai komponen yang berhubungan satu dengan yang lain, komponen tersebut meliputi tujuan, materi, metode, dan evaluasi (Rusman, 2012:93). Pengertian Media Pemb-elajaran menurut gagne dan Briggs dalam Azhar Arsyad (2014: 4) media pembelajaran adalah meliputi secara fisik digunakan untuk menyampaikan isi meteri pengajaran yang terdiri antara lain buku, tape recoreder, film, slide,foto, gambar, grafik, televisi, dan komputer.

Hamalik mengemukakan bahwa dalam pembelajaran, media memegang peran penting dalam mencapai sebuah tujuan belajar. Hubungan komunikasi antara dosen dan mahasiswa akan lebih baik dan efisien jika menggunakan media. Media dalam proses belajar mengajar memiliki dua peranan penting yaitu: (1) media sebagai alat bantu mengajar atau disebut sebagai dependent media karena posisi media di sini sebagai alat bantu (efektifitas), dan (2) media sebagai sumber belajar yang digunakan sendiri oleh peserta didik secara mandiri atau disebut independent media dirancang secara sistematis agar dapat menyalurkan informasi secara terarah untuk mencapai tujuan pembelajaran yang telah ditentukan.

Media pembelajaran yang baik harus memenuhi beberapa prasyarat. Media pembelajaran harus membangun inspirasi siswa. Pemanfaatan media bertujuan untuk memberikan inspirasi bagi mahasiswa. Selain itu, media juga harus menghidupkan mahasi-swa untuk mengingat kembali apa yang telah mereka sadari serta memberikan dorongan belajar yang baru. Media yang baik juga akan menggerakkan siswa dalam memberikan reaksi, masukan juga mendorong siswa untuk berlatih dengan benar, situasi media pembelajaran adalah mengingat bahwa sistem pembelajaran merupakan interaksi korespondensi dan terjadi dalam suatu kerangka, 
maka media pembelajaran melibatkan situasi yang benar-benar signifikan sebagai salah satu bagian dari kerangka pembelajaran. Tanpa media korespondensi tidak akan terjadi dan sistem pembelajaran sebagai interaksi korespondensi juga tidak dapat terjadi secara ideal. Media pembelajaran merupakan bagian dasar dari kerangka pembelajaran. Sehingga cenderung dianggap bahwa media pembelajaran merupakan bagian yang tidak terpisahkan dari proses pengajaran dan pembelajaran untuk mencapai tujuan instruktif secara keseluruhan dan tujuan pembelajaran di sekolah pada khususnya.

Pembelajaran dengan perangkat media visual memberikan manfaat, seperti menggali kejujuran emosional individu, menciptakan komunikasi yang efektif dan menyediakan fleksibilitas dalam aktifitas belajar (Turkoguz : 2012). Sedangkan menurut Djamarah (2010: 120) media pembelajaran adalah segala alat yang digunakan oleh guru dalam proses belajar.

\section{B. Pembelajaran Berbasis web}

Teknologi Data dan Komunikasi pada dasarnya merupakan suatu penyelidikan ilmu dalam menggarap kelangsungan hidup proses komunikasi. Teknologi Data dan Komunikasi dapat dikatakan sebagai ilmu yang diharapkan dapat mengawasi data dengan tujuan agar informasi dapat menjadi metode atau teknik untuk menyimpan data secara produktif dan layak. Inovasi data (Teknologi Informasi) sendiri mulai dikenal pada tahun 70-an yang bertekad untuk bereaksi terhadap berbagai kesulitan saat itu. Sebelumnya, istilah inovasi PC atau informasi elektronik papan atau EPD (Electronic Data Processing).

Kaitannya dengan program yang dibuat adalah bahwa untuk membantu keterkaitan TIK ini harus disertai dengan aplikasi yang sukses sebagai diskusi atau kantor sehingga dapat menyesuaikan setiap perkembangan kemajuan dari hasil mekanis seperti sekarang, lebih luas lagi nanti, oleh karena itu analis akan mencoba untuk mengeksploitasi Pembelajaran online atau berbasis web sebagai salah satu proyek relevan yang mungkin sangat layak untuk menjawab pertanyaan ini.

Sedangkan teknologi komunikasi secara singkat berarti teknologi yang memungkinkan manusia untuk saling berkomunikasi dengan lebih mudah. Teknologi komunikasi memiliki arti segala sesuatu yang berhubungan dengan penggunaan alat bantu untuk mengolah dan mentransfer data dari satu perangkat ke perangkat lainnya. Oleh karena itu, teknologi informasi dan komunikasi adalah padanan yang tidak terpisahkan yang mengandung pengertian luas tentang segala aspek yang berkaitan dengan pengolahan, manipulasi, pengelolaan, dan pemindahan/pemindahan informasi antar media dengan menggunakan teknologi tertentu.

ICT (Information and Communication Technology), atau yang diidentikkan dengan istilah tersebut, sangat tepat untuk dimanfaatkan di dunia Pendidikan baik pendiikan dasar menengah ataupun perguruan tinggi, Pemanfaatan ICT (Information and Communication Technology) di mana saja, harus mempertimbangkan kapasitas, kerangka kerja, dan komitmen besar pemanfaatannya, pemanfaatan TIK (Teknologi Informasi dan Komunikasi) secara mendasar mempengaruhi bidang berbagai wawasan yang membuat masyarakat belajar yang saat ini tidak terikat pada pembelajaran biasa. Kemampuan dan kemampuan kompuiter dalam pembelajaran adalah kemampuan yang berkaitan dengan pengetahuan, perkembangan intelektual, imajinasi, dan kemajuan, perencanaan, visual, pembelajaran virtual, dll. TIK (Teknologi Informasi dan Komunikasi) juga merupakan bidang penting dari kesadaran buatan manusia dalam waktu TIK.

\section{Motivasi Belajar}

Menurut Uno (2017:93) motivasi belajar merupakan dorongan internal dan eksternal pada siswa siswa yang sedang belajar untuk mengadakan perubahan tingkah laku, pada umumnya dengan beberapa indikator atau unsur yang mendukung. Motivasi adalah suatu perubahan energy di dalam pribadi seseorang yang ditandai dengan timbulnya afektif (perasaan) dan reaksi untuk mencapai tujuan (Kompri 2016:229). Motivasi merupakan penentu intensitas usaha belajar siswa, sebagai daya penggerak dan menjamin kelangsungan belajar siswa sehingga tujuan yang dikehendaki dapat tercapai (Prasetyo,dkk : 2015). Proses pembelajaran motivasi merupakan salah satu aspek dinamis yang sangat penting (Wina Sanjaya : 2010). Sering terjadi siswa yang kurang berprestasi bukan disebabkan oleh kemampuannya yang kurang, akan tetapi dikarenakan tidak adanya motivasi untuk belajar sehingga tidak berusaha 
untuk mengarahkan segala kemam-puannya. Indikator motivasi belajar menurut Uno (2011:23) menyebutkan indikator indikator motivasi belajar yaitu:

1. Adanya hasrat dan keinginan berhasil.

2. Adanya dorongan dan kebutuhan dalam belajar

3. Adanya harapan dan cita cita masa depan.

4. Adanya penghargaan dalam belajar.

5. Adanya kegiatan menarik dalam belajar

6. Adanya lingkungan belajar yang kondusif, sehingga memungkinkan seorang siswa dapat belajar dengan baik.

\section{Hasil Belajar}

Hasil belajar merupakan kemampuan yang diperoleh individu setelah proses belajar berlangsung, yang dapat memberikan perubahan tingkah laku baik pengetahuan, pemahaman, sikap dan keterampilan siswa sehingga menjadi lebih baik dari sebelumnya (Sanjaya : 2011:228-229). Berdasarkan pengertian tersebut maka dapat disintesiskan bahwa hasil belajar adalah suatu penilaian akhir dari proses dan pengenalan yang telah dilakukan berulang-ulang serta akan tersimpan dalam jangka waktu lama atau bahkan tidak akan hilang selama-lamanya karena hasil belajar turut serta dalam membentuk pribadi individu yang selalu ingin mencapai hasil yang lebih baik lagi sehingga akan merubah cara berfikir serta mengahasilkan perilaku kerja yang lebih baik. Hasil belajar dapat menggambarkan kemampuan siswa setelah apa yang mereka ketahui dan pelajari (Molstad dan Karseth : 2016).

Hasil belajar menunjukkan kemampuan mahasiswa yang sebenarnya yang telah mengalami proses pengalihan ilmu pengetahuan dari seseorang yang dapat dikatakan dewasa atau memiliki pengetahuan kurang. Jadi dengan adanya hasil belajar, orang dapat mengetahui seberapa jauh mahasiswa dapat menangkap, memahami, memiliki materi perkuliahan tertentu.

\section{METODE PENELITIAN}

Penelitian ini merupakan penelitian kuantitatif menggunakan metode eksperimen dengan tujuan untuk mengetahui pengaruh penggunaan media pembelajaran berbasis web terhadap motivasi dan hasil belajar mahasiswa. Eksperimen dilakukan dengan maksud dan tujuan melihat suatu akibat yaitu penerapan media pembelajaran berbasis web terhadap motivasi dan hasil belajar mahasiswa dalam kondisi terkendali (Kontrol). Variabel bebas dalam penelitian ini yaitu media pembelajaran berbasis web, sedangkan sebagai variabel terikat yaitu motivasi (Y1) dan hasil belajar (Y2). Metode eksperimen adalah suatu cara untuk mencari hubungan sebab akibat antara dua faktor yang sengaja ditimbulkan oleh peneliti dengan mengeliminasi atau mengurangi faktorfaktor menggangu (Arikunto, 2010:9). sampel yang digunakan dalam penelitian ini menggunakan dua kelas yaitu kelas eksperimen dan kelas kontrol. Kelas eksperimen menggunakan media pembelajaran berbasis website sedangkan kelas kontrol menggunakan metode ceramah (metode konvensional), peneliti akan mencari perbedaan antara motivasi dan hasil belajar mahasiswa pada kelas eksperimen dan kelas kontrol Variabel penelitian ini yaitu pengaruh penggunaan media pembelajaran berbasis web $(\mathrm{X})$ sebagai variabel idependen, dan Motivasi (Y1) dan Hasil belajar (Y2) sebagai variabel dependen, beberapa langkah pembelajaran yang dilakukan dalam penelitian ini adalah sebagai berikut: Pada Kelas yang mendapatkan perlakuan, pembelajaran dilakukan dengan menggunakan bantuan media pembelajaran berbasis web yang telah disiapkan sebelumnya. Sebelum pembelajaran di mulai, peneliti terlebih dahulu melakukan pretest pada mahasiswa dengan menggunakan soal essay. Pada pertemun terakhir, pada kelas perlakuan mahasiswa akan diberikan test akhir posttest menggunakan soal yang persis sama pada saat pretest. Pada Kelas kontrol, pembelajaran tidak dilakukan dengan bantuan media pembelajaran berbasis web, tetapi menggunakan metode konvensional, yaitu dengan metode ceramah dan bantuan papan tulis ataupun slide. Sama seperti pada Kelas eksperimen, pada Kelaskontrol sebelum dilakukan pembelajaran, terlebih dahulu peneliti memberikan soal pretest pada mahasiswa. Pada pertemuan akhir pun peneliti memberikan soal posttest pada mahasiswa. Soal pretest dan posttest yang diberikan pada Kelas kontrol merupakan soal yang sama yang juga diberikan pada Kelas eksperimen.

Instrumen yang digunakan dalam penelitian ini adalah berbentuk tes berupa soal pretest dan posttest. Soal yang digunakan pada saat pretest dan posttest adalah soal yang persis sama. Hal ini dilakukan untuk mengetahui adanya perbedaan ataupun peningkatan baik sebelum ataupun sesudah diberikan perlakuan yang berbeda diantara kedua kelas tersebut. 
Sugiyono mengatakan (2011:92) "Skala Pengukuran merupakan kesepakatan yang digunakan sebagai acuan untuk menentukan panjang pendeknya interval yang ada dalam alat ukur, sehingga alat ukur tersebut bila digunakan dalam pengukuran akan menghasilkan data kuantitatif, dalam penelitian ini, penulis meggunakan skala pengukuran dalam menyusun kuesioner dengan menggunakan Skala Likert. Skala Likert digunakan untuk mengukur sikap, pendapat, dan presepsi seseorang atau seKelasorang tentang fenomena sosial. Dalam penelitian, fenemona sosial ini telah ditetapkan secara spesifik oleh peneliti, yang selanjutnya disebut sebagai variabel penelitian (Sugiyono 2011:93)

Dengan menggunakan skala likert, maka variabel yang akan diukur dijabarkan menjadi indikator variabel. Kemudian indikator tersebut dijadikan acuan untuk menyusun item-item instrumen yang dapat berupa pertanyaan atau pernyataan, jawaban setiap item instrumen yang menggunakan skala likert mempunyai gradasi dari sangat positif sampai sangat negatif, yang dapat berupa kata-kata lain:

1. Sangat Setuju

2. Setuju

3. Ragu-ragu

4. Kadang-kadang

5. Sangat Tidak setuju

Sugiyono (2011:80) menjelaskan bahwa populasi adalah wilayah generalisasi yang terdiri atas obyek atau subyek yang mempunyai kualitas dan karakteristik tertentu yang ditetapkan oleh penelitian untuk dipelajari dan kemudian ditarik kesimpulannya, Jadi populasi bukan hanya orang, tetapi juga obyek dan bendabenda alam yang lain. Populasi juga bukan sekedar Jumlah yang ada pada obyek atau subyek yang dipelajari, tetapi meliputi seluruh karakteristik atau sifat yang dimiliki oleh subyek atau obyek itu. Populasi dalam penelitian ini adalah mahasiswa Semester VI (enam) STTIKOM Insan Unggul yang tediri dari dua kelas terdiri dari 31 mahasiswa kelas eksperimen dan 20 mahasiswa pada kelas kontrol. Penelitian dilakukan pada tahun akademik 2020/2021

\section{HASIL DAN PEMBAHASAN}

A. Pengaruh Penggunaan Media Belajar Berbasis Web Terhadap Motivasi Belajar Mahasiswa STTIKOM Insan Unggul

Pembelajaran ini diujicobakan di kelas TI18R1 dan dibandingkan dengan kelas lain, kelas TI18R2 sebagai pengontrol variabel lainnya. Oleh karena itu, desain penelitian diharapkan dapat menjawab hipotesis penelitian ini, pada analisis pertama, hasil motivasi untuk kelas eksperimen dan kontrol menunjukkan bahwa rata-rata gain untuk kelas eksperimen adalah 4.705 dan rata-rata win rate untuk kelas kontrol adalah 4.705 , jadi berbasis web. ternyata pembelajaran dengan menggunakan media berpengaruh terhadap motivasi belajar mahasiswa. Kelasnya adalah 7.915. Selisih 12,54 dan tingkat persentase $1,68 \%$. Artinya hipotesis nol (H0) yang diajukan dalam penelitian ini ditolak dan hipotesis alternatif $\mathrm{Ha}$ ) diterima. Oleh karena itu pembelajaran dalam media berbasis web telah mempengaruhi motivasi belajar mahasiswa di STTIKOM Insan Unggul. Analisis diatas dapat dilihat pada gambar di bawah ini:

Tabel 1. Rata-rata terhadap Motivasi belajar mahasiswa

\begin{tabular}{lccccccc}
\hline & \multicolumn{5}{c}{ Aspek Motivasi } & \multirow{2}{*}{ Rerata Selisih Pesentase } \\
\cline { 2 - 6 } Kelas & MinatPerhatianKonsentrasiKetekunan & & \\
\hline Eksperimen & 7,85 & 8,62 & 6,20 & 9,98 & 8,613 & & \\
\hline Kontrol & 4,69 & 5,29 & 3,77 & 5,19 & 4,735 & 13,54 & $1,82 \%$ \\
\hline
\end{tabular}

Tabel 2. Rata-Rata Pengaruh Media

Pembelajaran Berbasis web terhadap hasil belajar Mahasiswa

\begin{tabular}{lccccccc}
\hline & $\begin{array}{c}\text { Nilai Min } \\
\text { Pre-Test }\end{array}$ & $\begin{array}{c}\text { Nilai Mak } \\
\text { Pre-Test }\end{array}$ & $\begin{array}{c}\text { Nilai Min } \\
\text { Post-Test }\end{array}$ & $\begin{array}{c}\text { Nilai Mak } \\
\text { Post-Test }\end{array}$ & $\begin{array}{c}\text { Rerata } \\
\text { Pre dan } \\
\text { Post }\end{array}$ & Selisih \\
\hline Eksperimen & 50 & 78 & 76 & 100 & 152,47 & \multirow{2}{*}{12,7} \\
\hline Kontrol & 48 & 76 & 72 & 88 & 139,77 & \\
\hline
\end{tabular}

B. Uji Hipotesis

Pengujian hipotesis dilakukan dengan melakukan statistic non parametik, dengan uji bertanda wilcoxon. Uji ini seperti uji t dalam statistik parametik tetapi berdasarkan sistem peringkat. Dalam penelitian ini data yang digunakan adalah skor hasil belajar sebelum diberikan perlakuan (pre-test) dan yang sudah diberikan perlakuan (post-test). Data yang terkumpul berasal dari 20 subyek pada kelas kontrol dan 31 subyek pada kelas eksperimen. Angka yang digunakan untuk mencari ada tidaknya pengaruh penerapan media pembelajaran macromedia flash terhadap hasil bejar mahasiswa pada kelas yang tidak diberikan perlakuan (kelas kotrol). Angka selisih antara skor subjek pada skala hasil belajar mahasiswa pre-test dan posttest. Pegujian statistik dilakukan dengan uji statistik non parametik, yaitu dengan uji wilcoxon dan $\alpha=5 \%$. Hasil dari uji wilcoxon sebagai berikut:

Tabel 3. Nilai pre-Tests Descriptive Statistics 


\begin{tabular}{lccccc}
\hline & N & Minimum & Maximum & Mean & $\begin{array}{c}\text { Std. } \\
\text { Deviation }\end{array}$ \\
\hline $\begin{array}{l}\text { Pre-Test Kelas } \\
\text { Eksperimen }\end{array}$ & 31 & 50.00 & 78.00 & 65.29 & 6.41973 \\
\hline $\begin{array}{l}\text { Pre-Test Kelas Kontrol } \\
\text { Post-Test Kelas }\end{array}$ & 20 & 48.00 & 76.00 & 62.22 & 8.88856 \\
\hline $\begin{array}{l}\text { Eksperimen } \\
\text { Post-Test Kelas Kontrol }\end{array}$ & 20 & 76.00 & 100.00 & 86.58 & 5.89222 \\
\hline
\end{tabular}

\section{Keterangan:}

1. N menyatakan nilai data yang diproses yaitu 31 untuk kelas eksperimen dan 20 untuk kelas control.

2. Untuk kolom minimum menunjukan nilai pre test terendah.

3. Untuk kolom maximum merupakan nilai pre test tertinggi

4. Untuk kolom mean menunjukan nilai rata rata yang diperoleg dari pre test

5. Untuk kolom std.deviation menunjukkan nilai standart deviasi atau simpangan baku data.

Dari tabel di atas terlihat bahwa terdapat perbedaan hasil belajar mahasiswa yang signifikan antara mahasiswa pada kelas perlakuan dan kelompok perlakuan. Rerata pre-test di kelas eksperimen 65,89 , rerata pretest di kelas kontrol 62,22, post-treatment, hasil post-test di kelas eksperimen 86,58, dan hasil post-test di kelas kontrol. adalah Peningkatan yang terjadi antara pre-test eksperimen dengan post-test eksperimen sebesar 20.69 dan peningkatan yang terjadi antara pre-test kelas kontrol dan post-test pada kelas kontrol sebesar 15.33. Nilai pretest pada kelas eksperimen nilai minimum sebesar 50 dan nilai maksimum 78. Nilai pretest pada kelas kontrol nilai minimum sebesar 48 dan nilai maksimum 76 . Nilai post-test pada kelas eksperimen nilai minimum sebesar 76 dan nilai maksimum sebesar 100 . Nilai post-test pada kelas kontrol nilai minimum sebesar 72 dan nilai maksimum sebesar 88 .

Tabel 4. Wilcoxon Signed Ranks Test

\begin{tabular}{|c|c|c|c|c|}
\hline & & $\mathrm{N}$ & Mean Rank & $\begin{array}{l}\text { Sum of } \\
\text { Ranks }\end{array}$ \\
\hline \multirow{4}{*}{$\begin{array}{l}\text { Post-Test Eksperimen - } \\
\text { Pre-Test Eksperimen }\end{array}$} & Negative Ranks & $0 \mathrm{a}$ & .00 & .00 \\
\hline & Positive Ranks & $31 \mathrm{~b}$ & 16.00 & 496.00 \\
\hline & Ties & $0 \mathrm{c}$ & & \\
\hline & Total & 31 & & \\
\hline \multirow{4}{*}{$\begin{array}{l}\text { Post-Test Kontrol - Pre- } \\
\text { Test Kontrol }\end{array}$} & Negative Ranks & $0 \mathrm{a}$ & .00 & .00 \\
\hline & Positive Ranks & $20 \mathrm{~b}$ & 9.50 & 171.00 \\
\hline & Ties & $0 \mathrm{c}$ & & \\
\hline & Total & 20 & & \\
\hline
\end{tabular}

\section{Keterangan:}

1. post-test eksperimen
eksperimen
2. post-test eksperimen
eksperimen
3. Post-Test Eksperimen $=$ pre-test
Eksperimen

4. Post-Test Kontrol < Pre-Test Kontrol

5. Post-Test Kontrol $>$ Pre-Test Kontrol

6. Post-Test Kontrol $=$ Pre-Test Kontrol

Tabel 5. Test Statistics ${ }^{b}$

\begin{tabular}{|c|c|c|}
\hline & $\begin{array}{l}\text { Post-Test Eksperimen - } \\
\text { Pre-Test Eksperimen }\end{array}$ & $\begin{array}{l}\text { Post-Test Kontrol - Pre- } \\
\text { Test Kontrol }\end{array}$ \\
\hline Z & $-4.865^{a}$ & $-3.641^{a}$ \\
\hline Asymp. Sig. (2-tailed) & .001 & .001 \\
\hline
\end{tabular}

Keterangan:

1. Base on Negative ranks

2. Wilcoxon Signed Ranks Test

Melihat dan memperhatikan dari tabel di atas yang didapat dari statistik uji $t$ nilai post-test dan pre-test pada kelas eksperimen terdapat Z sebesar -4.865 atau sig $(0,001)<$ 0,005 . artinya valid. Sedangkan pada kelas kontrol mendapatkan $\mathrm{Z}$ sebesar -3.6411 atau sig. $(0,001)<0,005$ artinya valid, dari hasil analisis kedua menunjukkan pengaruh pembelajaran berbasis web terhadap hasil belajar siswa. Hal ini dibuktikan dengan hasil pre-test dan post-test pada kelas eksperimen dan kelas kontrol. menunjukkan bahwa nilai kelas eksperimen ini mencapai $62 \%$ meningkat hingga $81 \%$. ini menunjukkan bahwa media pembelajaran berbasis web berpengaruh terhadap hasil belajar mahasi-swa. Keberhasilan dalam meningkat-kan hasil belajar mahasiswa merupakan indikator penting tercapainya tujuan pembelajaran. Berbagai cara pengajar atau dalam hal ini adalah dosen dapat meningkatkan hasil belajar mahasiswa, seperti menggunakan media pembelajaran berbasis web. Dalam hal ini dosen atau pengajar berperan penting dalam memotivasi dengan menggunakan berbagai media pembelajaran, khususnya media pembelajaran berbasis web. Dengan media pembelajaran tersebut dalam hal ini pembelajaran berbasis web, membuat mahasiswa dalam situasi yang menyenangkan dan semangat belajar sehingga tidak pernah bosan saat belajar. Pengajar,guru atau dalam hal ini dosen yang kreatif dapat memotivasi siswa/ mahasiswanya untuk belajar.

Motivasi bertindak sebagai kekuatan pendorong untuk mencapai hasil belajar yang baik. Adanya motivasi belajar yang baik juga menunjukkan hasil yang baik. Keberhasilan belajar dicapai dengan hasil yang baik, karena motivasi mahasiswa sangat mempengaruhi pencapaian keberhasilan belajar. bahwa media dapat mengatasi keterbatasan pengalaman yang dimiliki mahasiswa, media dapat memungkinkan terjadinya interaksi langsung 
antara peserta dengan lingkungan, media daapat menghasilkan keseragaman pengamatan, Media juga dapat menyampaikan kebenaran, realitas, dan konsep dasar yang benar, dan media dapat membangkitkan keinginan dan minat baru, dan media dapat mengontrol kecepatan belajar siswa dan memberikan pengalaman yang utuh kepada mahasiswa, dari yang konkret sampai yang abstrak. Artinya pembelajaran media-centric berbasis web dapat mengubah sikap siswa terhadap pembelajaran dan meningkatkan hasil belajar. Perbedaan nilai motivasi antara kedua kelas menunjukkan perolehan hasil belajar siswa dan paralelisme atau linieritas, dan motivasi belajar siswa mendorong peningkatan hasil belajar siswa. Hal ini sesuai dengan pernyataan Djmarah bahwa media pendidikan dapat mengatasi perbedaan pengalaman diri pribadi dari berbagai kalangan mahasiswa mulai dari mahasiswa dalam kelompok mahasiswa yg berada dan mahasiswa miskin atau kalanagan tidak mampu. Motivasi merupakan dasar dari kegiatan manajemen, dan dengan menciptakan dan menumbuhkan motivasi yang tinggi, kita dapat mengusulkan pemanfaatan potensi dan sumber daya manusia, sehingga mahasiswa bekerja sama dalam mengerjakan tugas. Motivasi belajar bukan hanya tentang peran, melainkan tentang ukuran keberhasilan berdasarkan apa yang dikerjakan oleh seseorang. Ketika harapan seseorang terbentuk, mereka mulai belajar dari lingkungannya. Harapan selalu menyertakan standar keunggulan. Kriteria ini dapat muncul dari persyaratan orang tua atau lingkungan budaya di mana orang tersebut dibesarkan. Oleh karena itu, standar keunggulan adalah kerangka standar bagi mereka yang belajar untuk melakukan tugas, memecahkan masalah, dan mempelajari keterampilan lain untuk mencapai apa yang mereka butuhkan dan mereka harapkan. Mahasiswa yang bermotivasi tinggi cenderung lebih pintar di masa dewasa. Dengan kata lain, usaha seseorang karena kebutuhan hidup manusia meliputi kebutuhan untuk berbuat, dorongan untuk mengatasi rintangan, melatih kekuatan diri, dan menyelesaikan tugas-tugas sulit secepat mungkin.Menemukan atau melampaui keunggulan memenuhi kriteria. Di sini, motif seseorang ditentukan oleh dua faktor: harapan objek dan nilai objek. Semakin tinggi harapan seseorang terhadap suatu objek dan semakin tinggi nilai objek tersebut bagi orang tersebut maka semakin tinggi pula motivasinya. Oleh karena itu, memahami keunikan dan tingkat pertumbuhan dan perkembangan setiap anak dalam proses pembelajaran sejak anak usia dini hingga remaja merupakan faktor penting yang harus diperhatikan oleh seorang pendidik. Oleh karena itu, pengajar dalam hal ini seorang doesen harus mampu mengoptimalkan kreativitas dan motivasinya dalam meningkatkan baik motivasi maupun hasil belajar siswaatau mahasiswanya. Proses pembelajaran yaitu guru ataupun dosen yang dapat menciptakan kondisi belajar yang nyaman dan bermanfaat bagi siswa ataupun mahasiswanya akan memotivasi dan meningkatkan hasil belajar.

\section{SIMPULAN DAN SARAN}

\section{A. Simpulan}

Berdasarkan hasil penelitian dan pembahasan yang dipaparkan, dapat disimpulkan bahwa media pembelajaran berbasis web dapat ditingkatkan dengan metode eksperimen. Artinya, pada uji Wilcoxon, rata- rata yang diperoleh pada pretest kelas eksperimen adalah 65,89, rerata sebelum tes kelas kontrol adalah 62,22 , dan hasil post-treatment, posttest pada kelas eksperimen adalah 86,58, tetapi kontrol. Hasil setelah tes kelas adalah 77,55. Peningkatan antara pretest eksperimen dan posttest eksperimen adalah 20,69, dan peningkatan antara pretest kelas kontrol dan posttest kelas kontrol adalah 15,33. Nilai minimum untuk kelas eksperimen adalah 50 dan nilai maksimum adalah 78. Nilai pre-test untuk kelas kontrol minimal 48 dan maksimal 76. Nilai setelah dilakukan pengujian kelas eksperimen merupakan nilai terkecil. Nilainya 76 dan maksimal 100, tetapi nilai tes untuk kelas kontrol minimal 72 dan maksimal 88 . Hasil observasi motivasional sebelum menggunakan materi e-learning. tampak aspek motivasi memiliki minat dengan tingkat keberhasilan perhatian $67,50 \%$ dengan tingkat keberhasilan konsentrasi 5,21\% dengan tingkat keberhasilan ketekunan 3,89\% dengan tingkat keberhasilan 5,09\%. Dari data di atas dapat diperoleh bahwa rata-rata derajat keberhasilan yang dicapai cukup sebesar 17,32. Dan setelah dibenahi ternyata aspek motivasi belajar siswa terjaga dengan tingkat keberhasilan 7,58\% dengan tingkat keberhasilan 8,32\% dengan konsentrasi 8,32\%. Dari 9,96\% dari data di atas, rata-rata 
31,66 derajat baik dapat diperoleh. Berdasarkan data diatas maka dapat disimpulkan adanya peningkatan nilai setelah dilakukan pengujian terhadap kelas kontrol dan kelas eksperimen. Hal ini menunjukkan bahwa penggunaan media pembelajaran berpengaruh positif terhadap motivasi dan hasil belajar mahasiswa.

\section{B. Saran}

Untuk peneliti selanjutnya dapat menambah variabel serta dapat menyempurnakan metode yang lebih lanjut.

\section{DAFTAR RUJUKAN}

Aqib, Z. (2013). Model-Model Media dan Strategi Pembelajaran Konstektual (Innovatif). Jakarta: Yrama Widya.

Aqib, Z. (2013). Profesionalisme Guru dalam Pembelajaran (Edisi 4). Surabaya: Insan Cendikia.

Arikunto, S. (2015). Prosedur Penelitian Suatu Pendekatan Praktik. Jakarta: PT. Rineka Cipta.

Arsyad, A. (2014). Media Pembelajaran. Jakarta: Rajawali Pers.

Azhar, A. (2017). Media Pengajaran (Edisi Revisi). Jakarta: PT. Raja Grafindo Persada.

Darmawan, D. (2011). Teknologi Pembelajaran. Bandung: PT. Remaja Rosdakarya.

Dimyati, \& Mudjiono. (2009). Belajar dan Pembelajar. Jakarta: Rineka Cipta.

Djamarah, S. B. (2010). Belajar Mengajar. Jakarta: Rineka Cipta.

Hamlik, O. (2004). Pendidikan Guru Berdasarkan Kompetensi. Jakarta: PT. Bumi Aksara.

Hardianto, B. (2012). Database dengan Delphi7 menggunakan access ADO.

Kompri. (2016). Motivasi Pembelajaran Perspektif Guru dan Siswa. Bandung: PT. Rosda Karya.

Lubis, A. (2016). Basis Data Dasar. Yogyakarta: Deepublish.
Mølstad, C. E., \& Karseth, B. (2016). National Curricula in Norway and Findland : The Role of Learning Outcomes. SAGE Journal.

Mulyadi. (2010). Evaluasi Pendidikan Pengembangan Model Evaluasi Pendidikan Agama Di Sekolah. UIN-Maliki Press.

Oetomo, B. S., Wibowo, E., Hartono, E., \& Prakoso, S. (2007). Pengantar Teknologi Informasi Internet : Konsep dan Aplikasi. Yogyakarta: Andi.

Prasetyo, Y. D., Yektyastuti, R., Solihah, M., Ikhsan, J., \& Sugiyarto, K. H. (2015). Pengaruh penggunaan media pembelajaran kimia berbasis aplikasi android terhadap peningkatan motivasi siswa. Seminar Nasional Pendidikan Sains V, UNS.

Rusman. (2012). Belajar dan Pembelajaran Berbasis Komputer. Bandung: Alfabeta.

Sadjiman, A. R., Raharjo, R., Haryono, A., \& Harjito. (2011). Media Pembelajaran, Pengertian, Pengembangan, dan Pemanfaatannya. Jakarta: Rajawali Pers Rjagrafindo Persada.

Sanjaya, W. (2010). Kurikulum dan Pembelajaran. Jakarta: Kencana.

Sanjaya, W. (2011). Perencanaan dan Desain Sistem Pembelajaran. Jakarta: Kencana Prenada Media Group.

Sudjana, N. (2010). Dasar-dasar Proses Belajar. Bandung: Sinar Baru.

Suprijono, A. (2013). Cooperative Learning. Surabaya: Pustaka Belajar.

Turkoguz, S. (2012). Learn to teach chemistry using visual media tools. Journal Chemistry Education Research and Practise.13(4), 401-409.

Uno, H. B. (2017). Teori Motivasi dan Pengukuran nya. Yogyakarta: Bumi Aksara. 